\title{
Extramarital Affairs (EMA) for Indian Women: An Overview of its Health Impacts
}

\section{Sanjeev Davey*}

Professor, Department of Community Medicine, Muzaffarnagar Medical College, Muzaffarnagar, Uttar Pradesh, India

*Corresponding Author: Sanjeev Davey, Professor, Department of Community Medicine, Muzaffarnagar Medical College, Muzaffarnagar, Uttar Pradesh, India.
Received: February 14, 2020

Published: April 30, 2020

(C) All rights are reserved by Sanjeev Davey.

\section{Abstract}

Extramarital affairs (EMA) of men and women is becoming a rising Phenomenon in our modern society globally. Both men and women may get sexual and/or emotional motivations for EMA if their marriage is not satisfying in any aspect. EMA can put serious Impact on women if it is not secret. So, Couples should openly communicate regarding their sexual desires and expectations in their Married relationship to their partners.

Keywords: Extramarital Affairs (EMA); Indian Women; Health Impacts

\section{Introduction}

Marriage is the bond of two people to remain faithful to their partner in all times. But due to many reasons married people are making rethinking in the traditional approach to commitment [1]. Extramarital affairs (EMA) of men and women is becoming a common Phenomenon of our modern society and they are on the higher figures globally [1,2]. It is prevalent all across the globe and India is also getting affected by it in rising numbers. According to study by Kinsey., et al. nearly 50\% married men and $25 \%$ married women had at least one EMA during their lives [3]. Nearly $30 \%$ to $60 \%$ of all married individuals in the United States till 2019 were found to be engaged in infidelity even after their marriage. According to a survey conducted by Gleeden (an extra-marital dating app for married people with 600,000 users aging between 34 - 49 years), the number of people looking for an EMA has increased a lot [1].

\section{Types of EMA}

Extramarital affairs involve the infidelity in the form of physical, emotional, mental of anyone who is married [4,5]. There are variety of ways an Extramarital affairs also occurs such as Extramarital (EM) sex, Extramarital (EM) Love or infatuation etc. When Sex is done outside the marriage it is called ADULTERY [6]. Extramarital (EM) sex happens in 2 ways in one way when a married person is involved in sexual activity with anyone other than his spouse $[7,8]$ and another way is unmarried person having sex with a married or even unmarried girl or Call girls or even Prostitutes $[9,10]$.

\section{Factors responsible for EMA}

There are variety of factors, that can be contributory in EMA such as a) as excess of options at the workplace, b) social-media platforms, c) online dating sites d) lack of variety in a Sex relation- ship such as varied sexual needs in the form of oral sex in the form of Penis and vaginal sucking, Anal Sex, 6 by 9 sex position, Lesbianism and Homosexuality, e) too much porn addiction etc. f) emotional needs, and g) falling in love may be the possible reasons for beginning affairs $[10,11]$. Both men and women may get sexual or emotional motivations for EMA if their marriage is not satisfying in any above aspects [11].

Another reason may be heterosexual couples they may inclined extramarital affairs with regular frequency and other factors such as husband's and wife's age, wife's perception of domestic violence, husband's education and place of birth, husband's alcohol use, wife's willingness to engage in marital sex are also contributory in EMA [4]. In women, the domestic violence, denial of a preferred sex positions, longer erect penis, younger age and increased sexual satisfaction can also be the predictors of women's involvement in extra-marital partnerships [12].

Nearly $60 \%$ percent of men indicate that their wives could not refuse sex when they demanded it. Also, not only marital relationship and sexual satisfaction are important issue in extramarital sex, gender-based violence is also both a cause and a consequence of extramarital sex. It also appears from article in Times Newspapers that 77 per cent of Indian women cheat because they are bored by their monotonous married life. Since the Supreme Court of India abolished section 377 which criminalized same-sex extra-marital relationships, there was a +45 per cent increase in same-sex encounters among married people.

So India's most extramarital affairs have been reported from big metropolis such as: Bengaluru, Mumbai, and Kolkata [13]. 
A legal angle of EMA in Indian context

Majority of the countries worldwide treat adultery only as ground for civil issues including divorce and it continues to be so in India too [A]. Only a man who has consensual sexual intercourse with the wife of another man without his consent can be punished under this offence in India. If someone "lives in adultery", the partner can file for divorce. The law became defunct on 27 September 2018 by Supreme Court of India [13].

\section{Impact of extramarital affairs on Indian women}

In the short term, the discovery of an affair generally precludes a crisis for both partners and where this is not resolved, negative longer-term effects can be expected [14]. Xu and associates in their study found that a significantly higher number of abusive husbands had extramarital affairs and such affairs significantly predicted their wives being physically or sexually abused, or both, in their lifetime and in the previous year [15]. Fear of domestic violence among women is a major barrier to control over their own sexuality and their husbands' sexual activity outside of marriage [16]. As a result, wives are exposed to unsafe marital sex $[17,18]$ poor marital communication about sexual risk and sexuality, limited capacity for wives to refuse a husband's demand for sex, and limited use of condoms in marital sex as protection against disease transmission $[19,20]$.

\section{Home instability}

A study in Nigeria revealed that, there was not only significant relationship between extra-marital affair and reproductive health ( $r=.256, \mathrm{~N}=200, \mathrm{p}<0.05$ ) but also between extramarital affair and home instability. It was also established from this study that it threatens home stability and encourages the spread of sexually transmitted diseases such as HIV and AIDS and other STDs [21]. Similar Risks do remain for Indian women also.

\section{Risk of RTI, STI and HIV/AIDS}

Unsafe extramarital sex brings with it the risk of HIV and other sexually transmitted infections for both men and women in their communities. It also increases the risk that they will bring these infections to their wives. In addition, extramarital sex impacts on and is an indicator of difficulties in marriage that are manifested in social, economic, psychological and sexual interaction between spouses [2].

\section{Heart diseases}

An Extra-marital affair relationship can break heart. Extramarital affair women, according to a study, have a higher risk for heart disease. Turns out, for women, being extra-marital affair can be injurious to health. According to a study conducted by the New York University, extra-marital affair women have a higher risk for heart disease compared with non-extra-marital affair women across several modifiable risk factors [22,23].
Poor mental health

Poor mental health is a recognised risk factor for the development of heart disease," "Clinicians should be educated about sexual minority health and should routinely screen extra-marital affair women for mental distress as a risk factor for heart disease.

The importance of considering infidelity as a relational phenomenon, which reveals the importance of the relational approach in the treatment of couples who experience infidelity [24-26] because of their low status and culturally rooted gender discrimination, effective intervention will require sociocultural changes and economic empowerment of women $[25,26]$.

\section{Conclusion}

Couples should openly communicate their Sexual and love desires and expectations in their Married relationship to their partners, because simply choosing an open relationship may not guarantee higher levels of marital satisfaction, only then negative health effects of EMA in relationship can be curtailed in society.

\section{Bibliography}

1. Why do Indian women Cheat?

2. Ojedokun Isaiah Mobolaji. "Extramarital Affair As Correlate Of Reproductive Health And Home Instability Among Couples In Ibadan, Nigeria". Ajsw 5.2 (2015): 1-40.

3. Gilding Michael. "Rampant misattributed paternity: the creation of an urban myth". People and Place 13.12 (2005): 1-11.

4. Schensul SL., et al. "Men's extramarital sex, marital relationships and sexual risk in urban poor communities in India". Journal of Urban Health 83.4 (2006): 614-624.

5. Jack De Stefano Monica Oala. "Extramarital Affairs: Basic Considerations and Essential Tasks in Clinical Work". The Family Journal: Counseling and Therapy for Couples and Families 16 (2008): 13-19.

6. Adultery. Wikipedia.

7. Extramarital Sex. Wikipedia.

8. Bansi Pandit. "The Hindu Mind: Fundamentals of Hindu Religion and Philosophy for All Ages". 361 (2001).

9. Schensul SL., et al. "Men's extramarital sex, marital relationships and sexual risk in urban poor communities in India". Journal of Urban Health 83.4 (2006): 614-624.

10. Saengtienchai C., et al. "Prostitutes are better than lovers: wives' views on the extramarital sexual behavior of Thai men". In: Jackson PA, Cook NM, editions. Genders and Sexualities in Modern Thailand. Chian Mai: Silkworm (1999): 78-92. 
11. Julia Omarzu., et al. "Motivations and Emotional Consequences Related to Engaging in Extramarital Relationships". International Journal of Sexual Health 24.2 (2012): 154-162.

12. Y Kwena Z., et al. "Predictors of extra-marital partnerships among women married to fishermen along Lake Victoria in Kisumu County, Kenya". PLoS One 9.4 (2014): e95298.

13. Are extra-marital affairs legal in India?

14. Z Jahan Y., et al. "Factors involving extramarital affairs among married adults in Bangladesh". The International Journal of Community Medicine and Public Health 4 (2017): 1379-1386.

15. Xu X., et al. "Prevalence of and risk factors for intimate partner violence in China". American Journal of Public Health 95.1 (2005): 78-85.

16. Jejeebhoy S and Koenig M. "The social context of gynaecological morbidity: Correlates, consequences and health seeking behaviour". In: Jejeebhoy S, Koenig M, Elias C, eds. Investigating Reproductive Tract Infections and Other Gynaecological Disorders. United Kingdom: Cambridge University Press (2003).

17. Verma RK M and Collumbien M. "Wife beating and the links with poor sexual health and risk behaviour among men in urban slums in India". Journal of Comparative Family Studies (2003): 61-75.

18. Verma RK and Schensul SL. "Male sexual health problems in Mumbai". In: Verma RK, Pelto PJ, Schensul SL, Joshi A, eds. Sexuality in the Time of AIDS: Contemporary Perspectives from Communities in India. New Delhi: Sage (2004).

19. Ali MM., et al. "Condom use within marriage: a neglected HIV intervention". Bulletin of the World Health Organization 82.3 (2004): 180-186.

20. El-Bassel N., et al. "The efficacy of a relationship-based HIV/ STD prevention program for heterosexual couples". American Journal of Public Health 93.6 (2003): 963-969.

21. Obi Samuel N. "Extramarital sexual activity among infertile women in southeast Nigeria". The Journal of Obstetrics and Gynecology of India 56.1 (2006): 72-75.

22. Scheeren Patrícia., et al. "Marital Infidelity: The Experience of Men and Women". Trends in Psychology 26.1 (2018): 355-369.

23. Rahul Hajare. "Extra-Marital Affair Can Lead Trauma and Connections in Higher Risk for Heart Disease in Indian Women". Drug Designing Journal 2.1.
24. Bhattacharya G. "Sociocultural and behavioral contexts of condom use in heterosexual married couples in India: challenges to the HIV prevention program". Health Education and Behavior 31.1 (2004): 101-117.

25. Deswal Vageshwari. Are Extramarital affairs legal in India?.

26. Why Do Indian women Cheat? Times of India.

\section{Assets from publication with us}

- Prompt Acknowledgement after receiving the article

- Thorough Double blinded peer review

- Rapid Publication

- Issue of Publication Certificate

- High visibility of your Published work

Website: https://www.actascientific.com/

Submit Article: https://www.actascientific.com/submission.php Email us: editor@actascientific.com

Contact us: +919182824667 